\title{
La falta de motivación de las decisiones episcopales de revocación de la idoneidad de los profesores de religión y su control jurisdiccional
}

\author{
Lack of Motivation in Episcopal Decisions Concerning \\ the Revocation of Suitability for Religion Teachers \\ and Judicial Oversight
}

María del Carmen CAPARRós SOLER

Doctora en Derecho

Universidad Internacional de La Rioja (UNIR)

carmen.caparros@unir.net

Resumen: Conforme a la doctrina sentada por el Tribunal Constitucional a partir de su sentencia 38/2007, de 15 de febrero, la libertad de las confesiones religiosas para decidir acerca de la idoneidad de las personas encargadas de impartir su credo no está exenta de control por parte de los órganos jurisdiccionales del Estado, a fin de comprobar su ajuste a la legalidad y la compatibilidad de los motivos religiosos o morales invocados con los derechos fundamentales del profesor en su relación de trabajo. En este contexto adquiere una relevancia singular el hecho de que la autoridad eclesiástica haya explicitado o no por escrito los criterios de idoneidad que ha dejado de reunir el profesor para dejar de ser propuesto. Sobre todo si tenemos en cuenta que las revocaciones de idoneidad no constituyen decisiones no causales, sino que la autoridad eclesiástica se encuentra sujeta a condicionantes de orden moral o religioso, por lo que la exigencia de motivación puede resultar inherente a ello.

Palabras clave: Idoneidad eclesiástica, Revocación, Motivación, Control jurisdiccional.
Abstract: According to ruling 38/2007 issued by the Constitutional Court on 15 February of that year, the freedom of religious denominations to make decisions concerning the suitability of those entrusted to teach their creed is subject to some control by the courts so as to ensure that religious and moral concerns and the fundamental rights of the teacher as a working professional are lawful and compatible. In this regard, whether or not the church authority has set out in writing the eligibility criteria regulating teachers is of vital importance. Revocation of such suitability is not a no-fault decision; the church authority is subject to religious and moral criteria and, therefore, the need for grounds of motivation may be inherent to any such determination.

Keywords: Ecclesiastical Suitability, Revocation, Motivation, Judicial Review. 


\section{LA DOCTRINA DEL Tribunal CONSTITUCIONAL SOBRE EL CONTROL} JURISDICCIONAL DEL JUICIO EPISCOPAL DE IDONEIDAD

E 1 despido de los profesores de religión católica es uno de los temas que suscita mayor interés a los cultivadores del derecho eclesiástico español. Ese interés alcanza también a un buen número de iuslaboralistas. La decantación de la jurisprudencia del Tribunal Constitucional ha puesto de relieve cómo en esta materia entran en conflicto, junto a derechos de naturaleza ordinaria, derechos fundamentales del profesor frente al de libertad religiosa colectiva del que es titular la Iglesia católica. La piedra de toque para determinar si en ese conflicto ha sido realmente la preservación del derecho de libertad religiosa la causa del despido reside en el acto de revocación del ordinario. Esta revocación, tal como declara el Tribunal Constitucional en su sentencia $38 / 2007^{1}$, no es inmune frente a cualquier tipo de fiscalización jurisdiccional por parte de los órganos estatales ${ }^{2}$. De manera que, señala:

${ }^{1}$ STC 38/2007, de 15 de febrero (Boletín Oficial del Estado núm. 63, de 14 de marzo). El objeto de esta sentencia -recordemos- radicaba en resolver una cuestión de inconstitucionalidad promovida por la Sala de lo Social del Tribunal Superior de Justicia de Canarias en relación con el artículo III de Acuerdo con la Santa Sede sobre Enseñanza y Asuntos Culturales, suscrito el 3 de enero de 1979, y la disposición adicional segunda de la Ley Orgánica 1/1990, de 3 de octubre, de Ordenación General del Sistema Educativo, a los que se imputaba la vulneración del derecho de acceso al empleo público en condiciones de igualdad y de acuerdo con los principios de mérito y capacidad, al venir condicionada la contratación laboral por las Administraciones educativas de los profesores de religión, por la previa declaración eclesiástica de idoneidad, discriminando a los posibles candidatos en función de criterios religiosos.

2 La doctrina sentada por el Tribunal Constitucional en esta sentencia ocupa una posición cardinal dentro de este tema del control por los órganos jurisdiccionales del Estado de las decisiones eclesiásticas de revocación de la idoneidad por lo que ha sido objeto de numerosos comentarios doctrinales: C. Moreneo ATIENZA, La contratación de profesores de religión: control jurisdiccional de la declaración de idoneidad eclesiástica a raíz de la violación de los derechos fundamentales del trabajador (Comentario a la STC 38/2007, de 15 de febrero de 2007), Tribuna social: Revista de seguridad social y laboral 202 (2007) 47-51; J. OTADUY GUERÍN, Idoneidad de los profesores de religión. Una revisión necesaria y urgente. A propósito de la sentencia 38/2007, de 15 de febrero, del Tribunal Constitucional, Revista General de Derecho Canónico y de Derecho Eclesiástico del Estado 14 (2007) en http://www.iustel.com; G. Moreno Botella, Autonomía de la Iglesia, profesorado de religión y constitucionalidad del Acuerdo sobre enseñanza de 3 de enero de 1979. A propósito de la STC 38/2007 de 15 de febrero, Revista General de Derecho Canónico y de Derecho Eclesiástico del Estado 14 (2007) en http://www.iustel.com; J. FERREIRO GalgUERA, Sistema de elección del profesorado de religión católica en la escuela pública: dudas de constitucionalidad sobre sus cimientos normativos (STC 38/2007), Revista General de Derecho Canónico y de Derecho Eclesiástico del Estado 14 (2007) en http://www.iustel.com; A. Motilla DE LA CALLE, Consideraciones en torno al status jurídico de los profesores de religión católica (comentario de la STC 38/2007), Revista de la Facultad de Derecho de la Universidad de Granada 11 (2008) 257-267; M. CARdEnal CARRO - F. J. Hierro Hierro, La evolución bistórica de la regulación de los profesores de religión y moral católica como recurso para el juicio sobre la constitucionalidad de la vigente (A propósito de la STC 38/2007, de 15 de febrero), Revista del Ministerio de Trabajo e Inmigración 73 (2008) 205-246. 
«por más que haya de respetarse la libertad de criterio de las confesiones a la hora de establecer los contenidos de las enseñanzas religiosas y los criterios con arreglo a los cuales determinen la concurrencia de la cualificación necesaria para la contratación de una persona como profesor de su doctrina, tal libertad no es en modo alguno absoluta, como tampoco lo son los derechos reconocidos en el art. $16 \mathrm{CE}$ ni en ningún otro precepto de la Constitución, pues en todo caso han de operar las exigencias inexcusables de indemnidad del orden constitucional de valores y principios cifrado en la cláusula del orden público constitucional» ${ }^{3}$.

Establece, por tanto, una serie de pautas que han de guiar la revisión judicial de las decisiones de no continuidad del profesorado y que se constituyen, por consiguiente, en el canon de conformidad de aquéllas con la legalidad ordinaria y constitucional. Dichas directrices serían las que siguen:

«en primer lugar, los órganos judiciales habrán de controlar si la decisión administrativa se ha adoptado con sujeción a las previsiones legales a las que se acaba de hacer referencia, es decir, en lo esencial, si la designación se ha realizado entre las personas que el Diocesano ordinario ha propuesto para ejercer esta enseñanza y, dentro de las personas propuestas, en condiciones de igualdad y con respeto a los principios de mérito y capacidad. $\mathrm{O}$, en sentido negativo, y por ajustarse más a las circunstancias del caso analizado en el proceso a quo, habrán de analizar las razones de la falta de designación de una determinada persona y, en concreto, si ésta responde al hecho de no encontrarse la persona en cuestión incluida en la relación de las propuestas a tal fin por la autoridad eclesiástica, o a otros motivos igualmente controlables. Mas allá de este control de la actuación de la autoridad educativa, los órganos judiciales competentes habrán de analizar también si la falta de propuesta por parte del Ordinario del lugar responde a criterios de índole religiosa o moral determinantes de la inidoneidad de la persona en cuestión para impartir la enseñanza religiosa, criterios cuya definición corresponde a las autoridades religiosas en virtud del derecho de libertad religiosa y del principio de neutralidad religiosa del Estado, o si, por el contrario, se basa en otros motivos ajenos al derecho fundamental de libertad religiosa y no amparados por el

${ }^{3} \mathrm{FJ} 7$. 
mismo. En fin, una vez garantizada la motivación estrictamente "religiosa" de la decisión, el órgano judicial habrá de ponderar los eventuales derechos fundamentales en conflicto a fin de determinar cuál sea la modulación que el derecho de libertad religiosa que se ejerce a través de la enseñanza de la religión en los centros escolares pueda ocasionar en los propios derechos fundamentales de los trabajadores en su relación de trabajo» ${ }^{4}$.

Modulación que el Tribunal Constitucional entiende que el profesor de religión asume de forma voluntaria y libre cuando solicita la declaración de idoneidad para dedicarse a impartir enseñanza religiosa de una determinada confesión. De este modo, como se afirma en la sentencia:

«resultaría sencillamente irrazonable que la enseñanza religiosa en los centros escolares se llevase a cabo sin tomar en consideración como criterio de selección del profesorado las convicciones religiosas de las personas que libremente deciden concurrir a los puestos de trabajo correspondientes, y ello, precisamente, en garantía del propio derecho de libertad religiosa en su dimensión externa y colectiva» ${ }^{5}$.

De otra parte, a este respecto de la modulación que se produce en los derechos del profesor de religión también resulta especialmente significativa la doctrina sentada en esta sentencia acerca de las diferencias entre la relación entre profesores de religión y la Iglesia y la propia de una empresa de tendencia. Literalmente, se dice:

«resulta preciso constatar que las interrelaciones existentes entre los profesores de religión y la Iglesia no son estrictamente las propias de una empresa de tendencia, tal y como han sido analizadas en diversas ocasiones por este Tribunal, sino que configuran una categoría específica y singular, que presenta algunas similitudes pero también diferencias respecto de aquélla. La doctrina referente a las empresas de tendencia despliega toda su virtualidad en el ámbito de las relaciones laborales privadas y, por lo que hace en particular a la enseñanza, permite la modulación de los derechos del profesorado en consonancia con el ideario educativo de los centros privados (STC 47/1985, de 27 de marzo), cuya libertad de crea-

${ }^{4}$ Ibid.

5 FJ 12. 
ción comporta la posibilidad de dotarlos de un carácter u orientación propios (STC 5/1981, de 13 de febrero, FJ 8) como instrumento que son al servicio de las libertades individuales y colectivas garantizadas por los arts. 16 y 27 CE. Sin embargo, la condición que deriva de la exigencia de la declaración eclesiástica de idoneidad no consiste en la mera obligación de abstenerse de actuar en contra del ideario religioso, sino que alcanza, de manera más intensa, a la determinación de la propia capacidad para impartir la doctrina católica, entendida como un conjunto de convicciones religiosas fundadas en la fe. El que el objeto de la enseñanza religiosa lo constituya la transmisión no sólo de unos determinados conocimientos sino de la fe religiosa de quien la transmite, puede, con toda probabilidad, implicar un conjunto de exigencias que desbordan las limitaciones propias de una empresa de tendencia, comenzando por la implícita de que quien pretenda transmitir la fe religiosa profese él mismo dicha $f e{ }^{6}$.

Es importante poner de manifiesto que con el criterio interpretativo adoptado en esta sentencia el Tribunal Constitucional subvierte la línea jurisprudencial mantenida hasta ese momento por el Tribunal Supremo en este asunto del control jurisdiccional de las decisiones eclesiásticas de no propuesta $^{7}$. Según el parecer de este último, el carácter especial de la relación laboral de los profesores de religión, unido a la duración determinada del contrato, comportaban la exención de toda exigencia de motivación y, por consiguiente, de control a los obispos en sus determinaciones de no renovación de la idoneidad. Citando, por todas, la sentencia de 7 de julio de $2000^{8}$, de ella extraemos un pequeño fragmento, que resulta muy ilustrativo al respecto:

«En el espíritu y en la letra [del Acuerdo sobre la Enseñanza y Asuntos Culturales de 3 de enero de 1979 y de las normas y convenios que lo han desarrollado] late la idea de temporalidad de la relación de los profesores de religión católica, que se limita exclusivamente a la dura-

${ }^{6}$ FJ 10.

${ }^{7}$ Sobre este tema puede consultarse A. GonZález, Dos oportunidades perdidas. A propósito del control de la constitucionalidad de la designación por parte de la Iglesia de los profesores de religión en la escuela pública, Revista General de Derecho Constitucional 6 (2008) 1-27.

8 STS de 7 de julio de 2000 (ROJ STS 5588/2000). Las referencias jurisprudenciales se toman de la base de datos del Consejo General del Poder Judicial (CENDOJ). 
ción de cada curso escolar, y de ahí que la falta de inclusión en la propuesta del Ordinario para los cursos sucesivos, aunque el interesado hubiera impartido la enseñanza en los precedentes, no equivale a un despido, dada la peculiar naturaleza de la relación, cuya legitimidad hay que buscarla en el tratado internacional celebrado entre la Santa Sede y el Estado español el 3 de enero de 1979, y no en el artículo 15 del Estatuto de los Trabajadores, así es que las normas de la Ley estatutaria sobre el despido no resultan aquí aplicables. Partiendo de esa base hay que concluir afirmando que las reglas del Estatuto de los Trabajadores constituyen, a lo sumo, derecho supletorio para esta genuina relación laboral, aplicable en defecto de las que le son propias, y por eso mismo la causa que ha operado en este caso es la prevista en el artículo 49.1,c) del Estatuto de los Trabajadores, es decir, por la expiración del tiempo convenido. Así pues, para la extinción de la relación laboral no era necesario, como la sentencia recurrida da a entender, exponer las razones por las que el Arzobispado omitió la inclusión del demandante en la propuesta presentada a la autoridad educativa, porque ni existe norma que imponga tal deber, ni era necesario constatar los motivos de tal comportamiento, porque la relación quedaba automáticamente extinguida al finalizar el curso escolar para el que se había producido el nombramiento, que lo era para cada uno en particular, como se deduce de la normativa expuesta» ${ }^{9}$.

Sin embargo, como consecuencia de la aplicación de la doctrina sentada por el Tribunal Constitucional a partir de su sentencia 38/2007, el Tribunal Supremo rectifica su discurso interpretativo -sintetizado, como hemos visto, en su sentencia de 7 de julio de 2000 - y acoge la doctrina del Tribunal Constitucional, en virtud de la cual ni la naturaleza especial, ni el carácter temporal de esta relación laboral eximen a la decisión de no renovación del necesario respeto a los derechos fundamentales. Como ejemplo de este giro copernicano en su razonamiento puede citarse, entre otras, la sentencia del Tribunal Supremo de 28 de enero de $2009^{10}$, en la que, tras recordar su dilatado y -hasta ese momento- sólido criterio de que la naturaleza especial de la relación de los profesores de religión, surgida de un nombramiento o

\footnotetext{
9 FJ 7.

${ }^{10}$ (STS 674/2009).
} 
designación sólo para el curso escolar, implica que una vez cumplido el término (la finalización del curso escolar) queda extinguida, sin que la renovación automática, salvo propuesta en contra del ordinario, afecte a esa previa extinción, y sin que la falta de renovación tenga, en principio, que justificarse, reconoce que:

«ello no excluye que cuando está en juego la lesión de un derecho fundamental la justificación de que el cese o la no contratación son ajenos a esa lesión tenga que realizarse, porque, como establece la doctrina constitucional citada, en estos casos si el demandante de tutela acredita la existencia de indicios que ponen de relieve la posible concurrencia de una lesión de este tipo, no estamos ya ante un problema de legalidad ordinaria -la extinción por el cumplimiento de la condición resolutoria de un contrato-, sino ante un problema constitucional de protección de un derecho fundamental, que exige que se produzca esa justificación no en cuanto a la concurrencia de la causa de resolución, sino en cuanto a que la no formulación de la propuesta es una decisión extraña a cualquier propósito lesivo del derecho fundamental en cuestión» ${ }^{11}$.

Así pues, nuestros dos máximos -cada uno en su orden- órganos jurisdiccionales convienen en subrayar que la libertad de las confesiones para juzgar los criterios de cualificación ${ }^{12}$ de los profesores no puede resultar inmune al control judicial de los órganos del Estado, a fin de comprobar su ajuste a la legalidad y la compatibilidad de los motivos religiosos o morales invocados con los derechos fundamentales del profesor en su relación de trabajo. Ahora bien, en este orden de ideas adquiere una especial relevancia el hecho de que la autoridad eclesiástica haya explicitado o no por escrito los criterios de idoneidad que ha dejado de reunir el profesor para dejar de ser propuesto. De ahí que en las páginas que siguen nos vamos a centrar en analizar las singularidades que introduce en este contexto del control jurisdiccional de las decisiones episcopales de no renovación el hipotético supuesto de que no vayan acompañadas de ningún tipo de motivación.

${ }^{11}$ FJ 4.

12 Para un estudio más profundo de los requisitos para ser considerado idóneo como profesor de religión católica puede verse M. RODRíGUEZ BLANCO, El régimen jurídico de los profesores de religión en centros docentes públicos, Il diritto ecclesiastico 112/2 (2001) 482-573. 


\section{LA APLICACIÓN A LOS SUPUESTOS DE REVOCACIÓN DE LA IDONEIDAD} CARENTES DE MOTIVACIÓN DE LA DOCTRINA ACERCA DE LA TUTELA DEL TRABAJADOR FRENTE A ACTOS EMPRESARIALES DISCRIMINATORIOS

En efecto, en el juicio de constitucionalidad, que han de llevar a cabo los órganos judiciales sobre la decisión de la autoridad eclesiástica de dejar de proponer a un profesor de religión que hasta ese momento había venido prestando servicios, no resulta en absoluto intranscendente que aquélla dé razón o no de los motivos que le sirven de base. A este respecto ha de recordarse que el Tribunal Constitucional, en su sentencia 38/2007, encomienda a los jueces y tribunales el deber de analizar si la falta de propuesta por parte del Ordinario del lugar responde a criterios de índole religiosa o moral determinantes de la inidoneidad de la persona en cuestión para impartir la enseñanza religiosa, o si, por el contrario, se basa en otros motivos ajenos al derecho fundamental de libertad religiosa y no amparados por el mismo. De ahí que en los casos en que dicha justificación falta, tanto el Tribunal Supremo como el Tribunal Constitucional, en su jurisprudencia posterior a la sentencia 38/2007, resuelven esta ausencia haciendo aquí extensible la doctrina constitucional acerca de la tutela del trabajador frente a decisiones empresariales de no renovación de contratos temporales discriminatorias. En el caso de estas últimas, tal y como ha reconocido el Tribunal Constitucional, nos encontramos ante decisiones discrecionales comprendidas dentro de la libertad de contratación del empleador, que carecen de una causa prefijada, por lo que no precisan ser motivadas. Ahora bien, según la doctrina constitucional, eso no excluye que sean igualmente ilícitas por haber sido un motivo prohibido por discriminatorio y, consecuentemente, contrario a los derechos fundamentales del trabajador el que ha obstado a la reanudación de la relación laboral. Por consiguiente, tal y como sostiene el Tribunal Constitucional en su sentencia 29/2002, de 11 de febrero ${ }^{13}$,

«no puede sostenerse en modo alguno que sólo cuando está en curso una relación laboral pueda generarse una conducta discriminatoria, y, mucho menos, cuando esa relación laboral podría haber continuado normalmente, a través de la oportuna prórroga o nueva contratación sucesiva, de suerte que la discriminación puede viciar también actuaciones relativas al acceso al empleo o a su mantenimiento y cuando así ocurre los efectos

\footnotetext{
${ }^{13}$ Boletín Oficial del Estado núm. 63, de 14 de marzo.
} 
pueden ser equiparados a los de aquellas medidas que, en el ordenamiento laboral, impiden la continuidad del vínculo laboral por decisión unilateral del empresario, esto es, a los del despido fundado en la vulneración de un derecho fundamental, o sea, la ineficacia absoluta del acto empresarial extintivo, ilícito por discriminatorio» ${ }^{14}$.

De manera que, según el Tribunal Constitucional, los órganos judiciales no pueden limitarse a aducir que

«en el plano de la legalidad ordinaria la extinción de un contrato de trabajo temporal por la llegada de su término final opera como causa de finalización de la relación laboral [art. 49.1,c) LET] o que su renovación o conversión en otro por tiempo indefinido no resulta en principio obligada, perteneciendo esa medida al ámbito de la libertad de contratación del empleador. [...] La libertad de contratación [y] los poderes empresariales se encuentran limitados en su ejercicio no sólo por las normas legales o convencionales que los regulan, sino también por los derechos fundamentales del trabajador, constituyendo un resultado prohibido la utilización lesiva de éstos» ${ }^{15}$.

Sin embargo, esta pretendida equiparación entre la negativa de un empresario a renovar un contrato de trabajo temporal y la facultad episcopal de remoción de un profesor de religión no puede mantenerse sin las debidas reservas. Esto es, aunque la finalidad sea, mediante la comparación, extrapolar a las decisiones episcopales de revocación de la idoneidad el necesario respeto a los derechos fundamentales del trabajador y la posibilidad de su control judicial, lo cierto es que en el caso de estas últimas no estamos ante una resolución que pueda adoptarse por el ordinario según su libre apreciación personal -a diferencia de las otras, no se trata de una decisión no causal-, sino que, al margen de que no haga constar los motivos que sirven de base a su juicio, en verdad las causas por las que puede remover un profesor de religión están tasadas y deben responder, en todo caso, a «una razón de religión o moral» (canon 805). Esta potestad episcopal es consecuencia del cometido que el canon 804.2 encarga al ordinario del lugar de cuidar «de que los profesores que se destinan a la enseñanza de la religión en las escuelas, incluso en las no católicas, desta-

\footnotetext{
${ }^{14} \mathrm{FJ} 3$.

${ }^{15}$ FJ 7.
} 
quen por su recta doctrina, por el testimonio de su vida cristiana y por su aptitud pedagógica». De ahí que sólo en el caso de que la revocación de la idoneidad tenga un móvil religioso esté justificada. En este sentido, aunque en ambos casos los derechos fundamentales del trabajador constituyen un límite infranqueable, es obvio que el espectro de poderes empresariales que se enmarcan dentro de la libertad de contratación del empleador a la hora de no renovar un contrato es bastante más amplio que el que posee el obispo, condicionado -como se ha dicho- por una motivación exclusivamente religiosa.

Otro importante corolario del recurso a la doctrina constitucional sobre la protección jurisdiccional del trabajador frente a decisiones empresariales discriminatorias en el marco del control judicial de las decisiones episcopales de revocación de la idoneidad carentes de motivación es la aplicación de las reglas de la prueba indiciaria. La razón de ser de ésta estriba, según el Tribunal Constitucional, en la especial dificultad probatoria que acompaña a estos supuestos, por lo que resulta indispensable calibrar de forma proporcionada las reglas de distribución de la carga de la prueba para evitar que la imposibilidad en no pocas ocasiones de desvelar los auténticos motivos del acto empresarial impida declarar que éste ha resultado lesivo del derecho fundamental. Con esta finalidad acoge la mencionada prueba indiciaria, articulada en torno a un doble elemento:

$\ll$ El primero, la necesidad por parte del trabajador de aportar un indicio razonable de que el acto empresarial lesiona su derecho fundamental (STC 38/1986, de 21 de marzo, FJ 2), principio de prueba dirigido a poner de manifiesto, en su caso, el motivo oculto de aquél; un indicio que, como ha venido poniendo de relieve la jurisprudencia de este Tribunal, no consiste en la mera alegación de la vulneración constitucional, sino que debe permitir deducir la posibilidad de que aquélla se haya producido (así, SSTC 114/1989, de 22 de junio, FJ 5, y 85/1995, de 6 de junio, FJ 4). Sólo una vez cubierto este primer e inexcusable presupuesto, puede hacerse recaer sobre la parte demandada la carga de probar que su actuación tiene causas reales absolutamente extrañas a la pretendida vulneración de derechos fundamentales, así como que aquéllas tuvieron entidad suficiente como para adoptar la decisión, único medio de destruir la apariencia lesiva creada por los indicios» ${ }^{16}$.

\footnotetext{
${ }^{16}$ STC 140/2014, de 11 de septiembre (Boletín Oficial del Estado núm. 243, de 7 de octubre), FJ 7.
} 
Y respecto al primer elemento, esto es, la obligación del trabajador de aportar un principio de prueba suficiente indicativo de que se ha producido una vulneración constitucional recalca que

«no consiste en la mera constatación de que en un momento precedente tuvo lugar el ejercicio del derecho [...] sino que es preciso justificar -indiciariamente- la existencia de una relación de causalidad entre tal ejercicio y la decisión o acto calificado de lesivo del derecho. El que en un momento pasado se haya ejercitado un derecho fundamental constituye un presupuesto de la posibilidad misma de la violación denunciada, pero no un indicio de ésta que por sí solo desplace a la otra parte la obligación de probar la regularidad constitucional de su acto, pues la aportación de la prueba que concierne a la parte demandante deberá superar inexcusablemente el umbral mínimo de aquella conexión necesaria» ${ }^{17}$.

A la vista de estas exigencias, desde nuestro punto de vista, resulta obvia otra crítica. Y es que tanto el Tribunal Supremo como el Tribunal Constitucional no sólo avalan implícitamente el silencio del ordinario -como si se tratara de una decisión no causal que no es necesario justificar-, mediante su equiparación a resoluciones empresariales caracterizadas por la libertad del empresario para decidir sobre la continuación o no de la relación laboral, sino que además obligan al profesor de religión a suplir esta falta de motivación aportando un principio de prueba de que su cese tiene carácter atentatorio de alguno o algunos de sus derechos fundamentales. Por consiguiente, sólo en el caso de que el trabajador acredite indicios suficientes de una conducta discriminatoria por parte del ordinario, éste está obligado a proporcionar una justificación suficiente de que su decisión es ajena a todo propósito atentatorio del derecho de que se trate. Sin embargo, como ya se ha manifestado, este silogismo parte de la discutible premisa de que la decisión del ordinario es, empleando las propias palabras del Tribunal Supremo, «facultativa»y «por lo general no precisa ser argumentada». Esto nos conduce a distinguir, en lo que al objeto del presente trabajo nos interesa, dos momentos en los que la motivación debería -a nuestro entender- desplegar toda su virtualidad, que serían, en primer lugar, el momento en que el ordinario decide revocar la idoneidad por considerar que el profesor ha dejado de reunir las condiciones personales ne-

${ }^{17}$ Ibid. 
cesarias para impartir enseñanza religiosa de su credo; y, en segundo lugar, cuando la decisión de éste ha sido impugnada judicialmente por el profesor y va acompañada de la acreditación de indicios suficientes del panorama lesivo de sus derechos fundamentales.

\section{LA MOTIVACIÓN EN EL MOMENTO DE LA REVOCACIÓN DE LA IDONEIDAD POR EL ORDINARIO}

Sobre este particular resulta indispensable referirnos a la norma que actualmente regula la relación laboral de los profesores de religión, el Real Decreto 696/2007, de 1 de junio, dictado en desarrollo de la Disposición adicional tercera de la Ley Orgánica 2/2006, de 3 de mayo, de Educación. Dicho Real Decreto, como es sabido, introdujo cambios sustanciales en el régimen jurídico del profesorado de religión, que pueden sintetizarse en un nuevo sistema de contratación indefinida con renovación automática de la declaración eclesiástica de idoneidad ${ }^{18}$. Por lo que al objeto del presente apartado respecta, nos detendremos en su artículo 7, el cual incluye entre los supuestos de extinción del contrato de trabajo, concretamente en su apartado b), la revocación ajustada a derecho de la acreditación o de la idoneidad para impartir clases de religión por parte de la Confesión religiosa que la otorgó. Desde nuestro punto de vista, dentro de la necesaria conformidad a derecho de la remoción del profesor por revocación de la idoneidad deben entenderse comprendidos tres planos normativos: el plano del Derecho Canónico, el del Derecho Constitucional y el de la legalidad ordinaria. Así, en primer término, la sujeción del ordinario al Código de Derecho Canónico, en virtud de la cual únicamente una razón de índole religiosa o moral puede estar en la base de su negativa a continuar proponiendo a un profesor de religión, determina que la posible exigencia de que exponga abierta y oficialmente sus razones no implica un quebranto de su independencia, desde el momento en que no se le se exige nada a lo que no esté ya obligado. El matiz residiría, claro está, en la obligación de ex-

${ }^{18}$ Un análisis más detallado de esta nueva ordenación del régimen jurídico de los profesores de religión puede encontrarse en M. RODRíGUEZ BLANCO, El régimen jurídico de los profesores de religión y moral católicas, en M. CAMPO IBáÑEZ (ed.), Problemáticas y respuestas. Realidad actual y Derecho canónico. Actas de las XXXIII Fornadas de Actualidad Canónica, Dykinson, Madrid 2014, 109-138; M. J. GómEZ-Millán HerenCIA, Incidencia del Real Decreto 696/2007 en la contratación laboral de los profesores de religión católica, Relaciones laborales: Revista crítica de teoría y práctica 2 (2007) 1047-1075. 
teriorizarlas. Es más, conforme a las normas procedimentales del Código de Derecho Canónico, las decisiones de gobierno de la Iglesia -dentro de las cuales pueden entenderse englobados el reconocimiento o la retirada de la idoneidad- deben estar motivadas y debe garantizarse, asimismo, el derecho del fiel a ser escuchado ${ }^{19}$. En segundo término, el orden constitucional también representa un importante límite para esta competencia de las confesiones dirigida a juzgar sobre la idoneidad de las personas que hayan de impartir la enseñanza de su respectivo credo. Así, tal como se desprende de la doctrina del Tribunal Constitucional, por más que haya de respetarse la libertad de criterio de las confesiones, tal libertad no es en modo alguno absoluta, de donde se extrae que su derecho de libertad religiosa no ampara decisiones episcopales discriminatorias o contrarias a los derechos fundamentales ${ }^{20}$. En consecuencia, el

${ }^{19}$ Sobre este particular seguimos el mismo planteamiento que Otaduy, para quien «la retirada del encargo tendría que ser motivada, desde luego, en sede canónica y llevaría aparejada el reconocimiento del derecho a la impugnación del acto y al ejercicio de los correspondientes medios de defensa». J. OTADUY, Relación jurídica de los profesores de religión en España. La dimensión canónica, Ius Canonicum 92 (2006) 482. En el mismo sentido, IDEM, La idoneidad de los profesores de religión católica y su desarrollo jurisprudencial en España, Estudios Eclesiásticos 88 (2013) 854. Asimismo, compartimos el parecer de Cubillas Recio, cuando señala que el carácter discrecional de la propuesta del profesor de religión por parte del Ordinario no significa arbitrariedad, sino que «muy al contrario, supondrá un juicio crítico del proponente (elemento subjetivo) sobre la base de unos datos (elemento objetivo) que vendrán conformados por elementos normativos, como los contenidos en los cánones 804 y 805 del CIC». L. M. CuBILLAS, Confesionalidad y relación del profesor de religión católica en los centros públicos -Derecho español-, en M. BLANCO - B. CASTILLO J. A. Fuentes - M. SÁNCHEZ lasherAs (coords.), Ius et iura. Escritos de derecho eclesiástico y de derecho canónico en honor del profesor Juan Fornés, Comares, Granada 2010, 287 pp. En torno a esta prohibición de la arbitrariedad también se ha manifestado Brage Camazano, así, sostiene que «han de constar motivos para la decisión episcopal y han de ser de tipo religioso o moral; y no puede ser palmario que tales motivos no concurren en el caso concreto de que se trate; como el afectado puede recurrir la decisión episcopal como acto administrativo, debe valorarse si efectivamente tuvo esa posibilidad de recurso en el ámbito canónico, si hizo uso o no de ella y los motivos expresados por el tribunal eclesiástico al que recurriera». J. BRAGE, La no renovación de contrato a los profesores de religión en las escuelas públicas por falta de idoneidad canónica (autonomías de las iglesias y aconfesionalidad del Estado VS. derechos fundamentales del trabajador). Comentario a las SSTC 38/2007 y 128/2007, UNED. Teoría y Realidad Constitucional 20 (2007) 645.

20 En el mismo sentido, Llamazares Fernández apunta que «desde el punto de vista del Derecho estatal es requisito exigible, como condición de validez, que la propuesta o falta de propuesta estén motivadas y que las motivaciones, claro está, sean conformes o al menos no contradictorias con el Derecho del Estado, ni con el orden público, ni con los principios generales del derecho estatal laboral». D. LlamaZARES, Contratación laboral de los profesores de religión católica por la Administración Pública (Comentario a la STC 38/2007, de 15 de febrero), Revista Española de Derecho Constitucional 80 (2007) 283. Vid. también O. FERNÁNDEZ MÁRQUEZ, La designación del profesorado de religión y moral católica en centros públicos de enseñanza. Estado de la cuestión tras la STC 38/2007, de 15 de febrero, Revista Española de Derecho Constitucional 84 (2008) 307 y ss. 
control por los órganos del Estado de dicha decisión se alza como un expediente imprescindible para determinar su conformidad a derecho. De acuerdo con ello, los jueces y tribunales competentes habrán de verificar la motivación estrictamente religiosa de la decisión eclesiástica y, en caso de que consideraran que ésta ha quedado acreditada, llevar a cabo una operación de ponderación de los derechos fundamentales en conflicto a fin de determinar si la modulación producida en los derechos del profesor es rigurosamente necesaria para salvaguardar su compatibilidad con la libertad religiosa de la Iglesia católica. Para todo lo cual es fundamental que el ordinario explicite por escrito los requisitos que ha dejado de reunir el profesor de religión para dejar de considerarlo idóneo. A lo que cabría añadir que dicha obligación de justificar su decisión se deriva también de la incompetencia de los órganos estatales, en virtud de su deber de neutralidad, para definir los criterios morales o religiosos en que se funda el juicio negativo de idoneidad. Asimismo, no hay que olvidar que la Administración educativa se encuentra vinculada por la decisión eclesiástica y, por tanto, en caso de revocación de la idoneidad, está obligada -en cuanto auténtica empleadora- a hacer efectivo el cese, para lo que debe observar la normativa laboral que regula la extinción del contrato por voluntad del empresario, la cual conlleva una serie de obligaciones formales tales como la comunicación motivada en tiempo y forma. De manera que, como puede apreciarse, la motivación también encuentra fundamento en el plano de la legalidad ordinaria, aunque en este caso la Administración se limitará a reproducir -sin entrar a valorarlas- las razones aducidas por la autoridad eclesiástica, que es la única que genuinamente puede ofrecerlas en virtud -como se ha dichode la autonomía de las confesiones.

En cuanto al reflejo en el plano jurisprudencial del cambio normativo introducido por el Real Decreto 696/2007 puede traerse a colación la sentencia de 14 de enero de $2009^{21}$, en la que resulta significativo que califique la remoción o inhabilitación, que imposibilitaría la renovación del profesor en su puesto, como expresa. No obstante, no se pronuncia más allá de constatar la modificación normativa y omite cualquier pronunciamiento dirigido a desvelar el auténtico alcance de dicho carácter expreso, excusándose en la inaplicación de esta normativa al caso por un motivo cronológico, dado que el trabajador había sido cesado con anterioridad a que se aprobara.

${ }^{21}$ (STS 1464/2009). 
El Tribunal Constitucional, por su parte, como veremos a continuación en su sentencia 140/2014 tampoco impone abiertamente a la autoridad eclesiástica un deber de fundamentar la revocación de la idoneidad de un profesor de religión en el momento de adoptar dicha determinación, presumiblemente porque la forma de practicar la revocación no es una cuestión intrínsecamente constitucional, sino que pertenece al plano de la legalidad ordinaria. Sin embargo, quizá no resulte tan desatinado apreciar una dimensión constitucional en la falta de motivación en este punto, sobre todo si tenemos en cuenta el efecto pernicioso que sobre los derechos de defensa del profesor de religión produce. Por consiguiente, a nuestro entender, no puede negarse cierta entidad a una hipotética vulneración del derecho a la tutela judicial efectiva en su faceta de prohibición de la indefensión. Y, en este sentido, conviene recordar la definición que de esta última ofrece el Tribunal Constitucional en su sentencia 40/2002 22 : «la indefensión es una noción material que se caracteriza por suponer una privación o minoración sustancial del derecho de defensa; un menoscabo sensible de los principios de contradicción y de igualdad de las partes que impide o dificulta gravemente a una de ellas la posibilidad de alegar y acreditar en el proceso su propio derecho, o de replicar dialécticamente la posición contraria en igualdad de condiciones con las demás partes procesales ${ }^{23}$.

\section{LA MOTIVACIÓN TRAS LA IMPUGNACIÓN JUDICIAL DE LA DECISIÓN DE REVOCACIÓN}

\subsection{La necesaria acreditación de indicios de discriminación}

Como se ha visto, de acuerdo con la doctrina constitucional acerca de la tutela del trabajador frente a actos empresariales discriminatorios, la no desdeñable traba de demostrar que la decisión del empresario de no renovación de un contrato temporal ha obedecido a un móvil lesivo de los derechos del trabajador obliga a distribuir la carga de la prueba entre éste y el trabajador de una forma coherente a dicha dificultad. Por esta razón el Tribunal Constitucional recurre a las reglas de la prueba indiciaria, en virtud de la cual el trabajador debe aportar un principio de prueba del que pueda deducirse una rela-

22 STC 40/2002, de 14 de febrero (Boletín Oficial del Estado núm. 63, de 14 de marzo).

23 FJ 3. 
ción de causalidad entre el ejercicio del derecho y la determinación empresarial de no reanudar la relación laboral. Una vez acreditados los indicios de la posible lesión de los derechos fundamentales del trabajador, incumbe al empresario probar que su actuación responde a razones absolutamente ajenas a la denunciada vulneración.

Trasladado al tema que nos ocupa, la aplicación de esta doctrina por el Tribunal Supremo y el Tribunal Constitucional a los supuestos de revocación de la idoneidad a profesores de religión, carentes de motivación, implica que la obligación de la autoridad eclesiástica de ofrecer una justificación suficiente de que la decisión de excluir al profesor de la lista de habilitados no ha respondido a ningún propósito discriminatorio sólo resulta exigible si, con carácter previo, el profesor ha probado al menos indiciariamente que dicha decisión constituye una violación de alguno de sus derechos.

Por consiguiente, el deber de motivar queda aquí diferido y condicionado a que el profesor acredite la existencia de indicios que pongan de relieve la posible concurrencia de una lesión de sus derechos. De este modo, la aportación de un panorama lesivo adquiere una trascendencia capital, por lo que resulta conveniente incidir en los criterios que han seguido tanto el Tribunal Supremo como el Tribunal Constitucional a la hora de apreciar la suficiencia o no de los indicios alegados. A este respecto, ha de advertirse que la pauta adoptada por el Tribunal Constitucional en el único pronunciamiento que existe por el momento ha sido más estricta que la del Tribunal Supremo.

\subsection{La postura del Tribunal Constitucional}

El pronunciamiento a que se hace mención al final del apartado anterior aparece recogido en la sentencia del Tribunal Constitucional 140/2014, de 11 de septiembre, por la que se resuelve un recurso de amparo, promovido por una profesora de religión y moral católicas, que había venido prestando servicios desde 1997 en diversos centros de primaria de la Comunidad Autónoma de Canarias. Sin embargo, el 31 de mayo de 2002 el ordinario diocesano de Tenerife la incluyó en una lista de profesores no propuestos para ser contratados para el curso siguiente, en la que se omitían los criterios de idoneidad que habían dejado de reunir. No consta tampoco que dicha relación fuera comunicada a la demandante, la cual se enteró a través del Ministerio cuando al comienzo del curso no concertó contrato de trabajo con ella. 
Como consecuencia de ello, la recurrente presentó demanda de despido que fue estimada por la Sentencia de 2 de junio de 2003 del Juzgado de lo Social núm. 3 de Santa Cruz de Tenerife, mediante la que se declaró la existencia de despido nulo, por apreciar vulneración de los derechos de libertad sindical, tutela judicial efectiva e igualdad y no discriminación. Recurrida en suplicación por el Ministerio de Educación y por la diócesis de Tenerife, aquélla fue revocada por sentencia de la Sala de lo Social del Tribunal Superior de Justicia de Canarias de 7 de junio de 2004. En contra de la anterior sentencia se interpuso por la demandante recurso de casación para la unificación de doctrina, que fue desestimado por Sentencia de la Sala de lo Social del Tribunal Supremo de 8 de junio de 2006, sin entrar a resolver sobre el fondo del recurso, por falta de fundamentación de éste.

La demandante desde el principio alegó que su falta de propuesta había estado motivada por los siguientes hechos: a) la participación en una huelga en el curso 1999-2000; b) la interposición previa de una demanda de reclamación de relación laboral indefinida en el puesto de trabajo, que fue desestimada por el Tribunal Superior de Justicia de Canarias mediante sentencia de 22 de febrero de 2002; c) la remisión por el delegado diocesano de enseñanza en los años 2000 y 2001 de unas cartas de revisión de cuentas a los profesores de religión, con el objeto de conseguir la autofinanciación, pidiendo la colaboración con aportación económica calculada en un 0,6 por 100 del salario, habiéndose negado la demandante al pago de dichas cantidades; y d) haber contraído matrimonio con un hombre previamente divorciado. En primera instancia, el Juzgado de lo Social consideró que estos hechos constituían indicios suficientes de discriminación, por lo que al no ser desvirtuados por la parte demandada, determinaron la declaración de nulidad del despido. En contra de este parecer se manifestó la Sala de lo Social del Tribunal Superior de Justicia, en clara adhesión a la doctrina mantenida por ese entonces por el Tribunal Supremo. Así, con fundamento en el carácter temporal de esta relación laboral, que debía entenderse extinguida al finalizar el curso escolar, consideró innecesario el análisis de los motivos de la falta de propuesta e irrelevantes los indicios de violación de derechos fundamentales aportados por la demandante, sin que, por tanto, resultaran de aplicación las reglas de distribución de la carga de la prueba, pues se trataba asimismo de una relación laboral con una naturaleza específica, a la que no resultaban de aplicación las normas del Estatuto de los Trabajadores. En síntesis, para este Tribunal, al tratarse de una relación especial de duración determinada, el ordinario podía cesar a la profesora sin justificación alguna. 
Por consiguiente, revocada la sentencia del Juzgado de lo Social, que era la única que le había dado la razón, por la sentencia de la Sala de lo Social del Tribunal Superior de Justicia y desestimado por el Tribunal Supremo el recurso de casación para la unificación de doctrina interpuesto frente a ésta, la demandante acudió en amparo ante el Tribunal Constitucional, ante el que reiteró su pretensión de que declarara el carácter discriminatorio de su no contratación, desde el momento en que estuvo vinculada al ejercicio de derechos fundamentales como la participación en una huelga, la presentación de una demanda judicial de reconocimiento del carácter indefinido de la relación laboral, el haberse negado a contribuir a la diócesis con una parte de su salario y el hecho de haber contraído matrimonio con un ciudadano previamente divorciado.

Respecto a los tres primeros, el Tribunal Constitucional descarta la discriminación alegada, dado que no existe conexión temporal entre ellos y la decisión de no proponerla. En concreto, el ejercicio por la demandante del derecho de huelga para obtener de la Administración educativa una modificación de sus condiciones laborales se produjo durante el curso escolar 19992000. Igualmente, la reclamación judicial para que su relación laboral fuera declarada indefinida, tuvo lugar también en 1999. Finalmente, la negativa de la demandante a realizar una aportación del 0,6 por 100 de su salario para la autofinanciación de la delegación diocesana de enseñanza se produjo en el año 2000. Sin embargo, las circunstancias aludidas no provocaron que la demandante dejase de ser propuesta por el obispado de Tenerife para ser contratada como profesora durante los cursos escolares 2000-2001 y 2001-2002. En cuanto al último motivo aducido, el de haber contraído matrimonio con persona divorciada -que es el único que a juicio del Tribunal Constitucional guarda relación con el ejercicio colectivo de la libertad religiosa de la Iglesia Católica y justificaría la necesidad de ponderar la concurrencia de los distintos derechos fundamentales en juego- considera que tampoco se han acreditado suficientemente los indicios racionales de discriminación, dado que

«más allá de la alegación formulada por la demandante de que había contraído matrimonio con persona divorciada, no existe dato alguno en las actuaciones que permita tener por acreditada ni la fecha en la que este matrimonio tuvo lugar, ni si el matrimonio previo del otro contrayente era o no canónico e impeditivo de un subsiguiente matrimonio religioso con la demandante de amparo, ni si el Ordinario Diocesano tuvo o no conocimiento de esta circunstancia y, en su caso, en qué momento se pro- 
dujo a fin de apreciar su conexión temporal con la falta de llamamiento a una nueva contratación» ${ }^{24}$ (STC 140/2014, FJ 9).

Sin embargo, si reflexionamos sobre los criterios aplicados por el Tribunal Constitucional para medir la fuerza probatoria de los hechos aducidos por la profesora de religión como causantes de su cese, pueden dirigirse contra ellos algunos reproches.

Así, en cuanto a la necesaria conexión temporal entre las circunstancias alegadas por la demandante -la participación en la huelga, la reclamación judicial solicitando la conversión de su contrato en indefinido y la negativa a contribuir económicamente con la diócesis- y la decisión impugnada, el Tribunal Constitucional entiende que no existe, dado que aquéllas no fueron óbice para que siguiera siendo propuesta para los dos cursos escolares siguientes. Sin embargo, la potencial virtualidad probatoria de este criterio debe valorarse como algo relativo, ya que la conexión temporal podría quedar desvirtuada simplemente con que el ordinario retrasara uno o dos cursos académicos la revocación de la idoneidad.

A mayor abundamiento, resulta igualmente llamativo que el Tribunal Constitucional establezca una equivalencia entre el caso resuelto en esta sentencia y el de la sentencia 128/2007, de 4 de junio. De este modo, recuerda que en esta última también se valoró como relevante para descartar la discriminación alegada el dato de que el recurrente hubiese mantenido su puesto de profesor de religión y moral católica en los años siguientes a cuando el obispo tomó conocimiento de su condición de cura casado y con hijos y miembro del Movimiento pro-celibato opcional. En este caso, el desencadenante de su no renovación fue, según la justificación del obispado acogida por el voto mayoritario, que el recurrente diera publicidad y notoriedad a su situación mediante la aparición, junto a su familia, en una información gráfica difundida en un periódico, que se había hecho eco de una reunión celebrada por el Movimiento pro-celibato opcional, en la que había participado. Ahora bien, como ponen de manifiesto los Magistrados doña Elisa Pérez Vera y don Pascual Sala Sánchez en su voto particular a la sentencia: «el hecho de que esa realidad se hiciera pública no la transforma, ni transforma tampoco, consiguientemente, aquella circunstancia del conocimiento y la tolerancia previa de la Iglesia, de modo que no puede convertirse de forma sobrevenida en una razón de inadecuación para la docencia

24 STC 140/2014, FJ 9. 
cuando no impedía hasta la fecha la aptitud para la misma y para la transmisión de los valores religiosos que comporta. [...] En suma, la Iglesia ha hecho valer para la no renovación de la idoneidad del profesor una circunstancia personal que conocía, así como su discrepancia con una posición legítima del profesor amparada por la Constitución, que previamente consintió. Por tanto, las circunstancias del caso acreditan que los factores invocados para la inidoneidad del recurrente, pretendidamente amparados en la libertad religiosa de la Iglesia (art. 16.1 CE) y en su derecho consiguiente a decidir quién es apto para la docencia de la enseñanza religiosa, son elementos que la propia Iglesia, en atención a sus actos previos, no consideró relevantes para negar la idoneidad del profesor en los años anteriores. La publicidad de esos datos, por indeseada que fuera para la Iglesia, no esconde que los mismos nunca fueron antes considerados inhabilitantes para la impartición de la doctrina». Por esta razón, nos adherimos a la opinión de Cabeza Pereiro, para quien esta sentencia «en modo alguno avala la trascendencia del tiempo transcurrido entre los hechos alegados y la respuesta del Obispado en términos de no renovación del contrato» ${ }^{25}$, desde el momento en que no pueden ocultarse bajo el pretexto del escándalo, provocado por el hecho de que el recurrente hiciera pública su situación, los auténticos motivos del cese, sobradamente conocidos y tolerados por la Iglesia desde hacía años.

Por otro lado, el examen comparativo de otras personas en quienes también hubieran concurrido circunstancias semejantes también presenta en este caso una transcendencia limitada, dado que probablemente el Ordinario haya tomado en cuenta, junto a dichas circunstancias, otras cualidades o características eminentemente personales que, como sabemos, ocupan una posición bastante concluyente en el juicio de idoneidad. En este punto coincidimos también con Cabeza Pereiro cuando afirma que «el expediente seguido por el Tribunal, de combatir cada indicio aisladamente considerado, constituye una técnica falaz, pues desenfoca el problema. Es cierto que la demanda plural había sido firmada por más de 100 de personas, de las cuales sólo tres fueron propuestas para no renovación, pero con seguridad no todas ellas habían participado en la huelga ni estarían en una situación marital dígase que sospechosa desde el punto de vista del Derecho Canónico» ${ }^{26}$.

25 J. CABEZA, El control judicial sobre las decisiones episcopales relativas al profesorado de religión en centros públicos: comentario a una sentencia desafortunada con exabrupto en uno de los votos particulares. Sobre la STC 140/2014, de 11 de septiembre, Revista de Derecho Social 67 (2014) 162.

${ }^{26} \mathrm{Ibid}$. 
A lo anterior debe sumarse el propio valor indiciario de la total ausencia de motivación de la decisión episcopal. Respecto a este particular, cabe objetar que el Tribunal Constitucional, en lugar de considerar este silencio como un indicio más de que se han vulnerado los derechos fundamentales de la recurrente en amparo, paradójicamente lo utiliza como un argumento más de la insuficiencia de acreditación del panorama indiciario, de lo que resulta en palabras de Cabeza Pereiro «que la propia falta de transparencia en la decisión resolutoria al final se vuelve en contra de quien la sufre». Así, el Tribunal Constitucional manifiesta:

«a diferencia de lo que acontecía en los casos resueltos por las SSTC 128/2007, de 4 de junio, y 51/2011, de 14 de abril, en los cuales la Iglesia católica había expresado la razón por la que no se había llamado a los entonces demandantes a una nueva contratación (participación en el movimiento pro-celibato opcional y haber contraído matrimonio civil; y por haber contraído matrimonio civil con un divorciado, respectivamente), tal circunstancia no se da en el presente caso ni, como hemos visto, ha sido indiciariamente acreditada con las exigencias constitucionales a las que ya se hizo mención. Todo ello hace innecesaria la ponderación de tal supuesto indicio con el derecho a la libertad religiosa de la Iglesia Católica ${ }^{27}$.

Para completar esta reflexión crítica sobre la solución adoptada por el Tribunal Constitucional en su sentencia 140/2014 se considera igualmente importante poner el acento, esta vez, en la omisión, apuntada también por Cabeza Pereiro, de una sentencia capital dentro de la consolidada doctrina constitucional sobre la discriminación que afecta a la no renovación contractual y las pautas para determinar la suficiencia del panorama indiciario. Se trata de la sentencia 89/2000, de 21 de marzo, -cuya argumentación vuelve a ser reiterada en su sentencia 144/2006, de 8 de mayo- en virtud de la cual el actor

«ha de acreditar la existencia de algún elemento que, sin servir para formar de una manera plena la convicción del Juez sobre la existencia de hechos atentatorios contra el derecho fundamental, le induzca a una creencia racional sobre su posibilidad. Para apreciar la concurrencia del indicio tendrán aptitud probatoria, tanto los hechos que sean claramente indicativos de la probabilidad de la lesión del derecho sustantivo,

27 STC 140/2014, FJ 9. 
como aquellos que, pese a no generar una conexión tan patente, y resultar por tanto más difícilmente neutralizables, sean sin embargo de entidad suficiente para abrir razonablemente la hipótesis de la vulneración del derecho fundamental. Esto es, son admisibles diversos resultados de intensidad en la aportación de la prueba que concierne a la parte actora, pero habrá de superarse inexcusablemente el umbral mínimo de aquella conexión necesaria, pues de otro modo, si se funda la demanda en alegaciones meramente retóricas, o falta la acreditación de elementos cardinales para que la conexión misma pueda distinguirse, haciendo inverosímil la inferencia, no se podrá presentar el desplazamiento del onus probandi al demandado».

De manera que en el caso resuelto por la sentencia 140/2014 no resulta tan «inverosímil» sostener la hipotética vinculación entre los motivos alegados por la profesora y la decisión de no proponerla, sobre todo porque dos de ellos -la participación en una huelga y el haber contraído matrimonio con persona divorciada ${ }^{28}$ - han servido presunta o explícitamente de base en anteriores ocasiones para rescindir la idoneidad a otros profesores de religión. Podría ser aquí extrapolable -con las debidas reservas- la presunción que se establece en el Estatuto de los Trabajadores a favor de la trabajadora embarazada, en caso de despido, de modo que basta la existencia objetiva del embarazo, para trasladar al empresario la carga probatoria de que el despido se ha producido por causas no inherentes a dicho embarazo. De modo que, al igual que sucede con el embarazo, en el caso que nos ocupa debería haberse concedido a los hechos alegados por la demandante la «entidad suficiente para abrir razonablemente la hipótesis de la vulneración del derecho fundamental», dado que su intrínseca virtualidad motivadora del resultado negativo del juicio de idoneidad es más que razonable. No olvidemos que incluso uno de ellos, el haber contraído matrimonio con persona divorciada, no es precisamente el mejor ejemplo de testimonio y vida cristina. Y todo ello teniendo en cuenta que la calificación como suficiente del panorama indiciario no prejuzga en absoluto el sentido del fallo, sólo sirve para invertir la carga de la prueba, ya que la parte demandada puede destruir la apariencia lesiva creada por los indicios, demostrando que su actuación respondió a causas totalmente ajenas a la pretendida vulneración del derecho de que se trate.

${ }^{28}$ Vid. STC 51/2011, de 14 de abril (Boletín Oficial del Estado núm. 111, de 10 de mayo). 
En consecuencia, y pese a que de acuerdo con la doctrina sentada por el propio Tribunal Constitucional en su simbólica sentencia 38/2007, de 15 de febrero, los órganos judiciales estatales «habrán de analizar también si la falta de propuesta por parte del Ordinario del lugar responde a criterios de índole religiosa o moral determinantes de la inidoneidad de la persona en cuestión para impartir la enseñanza religiosa, criterios cuya definición corresponde a las autoridades religiosas en virtud del derecho de libertad religiosa y del principio de neutralidad religiosa del Estado, o si, por el contrario, se basa en otros motivos ajenos al derecho fundamental de libertad religiosa y no amparados por el mismo», en el caso planteado en la sentencia objeto de nuestro examen, paradójicamente, el Tribunal Constitucional omite dicho análisis argumentando que la demandante no ha aportado indicios suficientes de que se hayan vulnerado sus derechos fundamentales. De modo que, en lugar de indagar o exigir una aclaración que le permita confirmar la naturaleza estrictamente religiosa de la motivación, ampara -desde nuestro punto de vista indebidamente- la opacidad de la decisión eclesiástica y presume que es conforme a Derecho. En este sentido, tampoco alcanzamos a comprender por qué elude pronunciarse sobre la aplicación y alcance en este caso de la previsión del artículo 7.b) del Real Decreto 696/2007, que exige que la revocación sea ajustada a derecho y su incidencia en orden a la obligación de que aquélla se haga de forma motivada. Así pues, según se ha indicado más arriba, la exigencia de que la revocación sea ajustada a derecho incluye o se refiere a un triple plano normativo: el plano del Derecho Canónico, el del Derecho Constitucional y el de la legalidad ordinaria, en cada uno de los cuales pueden encontrarse razones que sirven de fundamento jurídico para sustentar el carácter preceptivo de la motivación. En efecto, y conforme a las normas del Código de Derecho Canónico, el obispo a la hora de decretar la no renovación de la propuesta del profesor de religión debe motivarla en cuando decisión de gobierno de la Iglesia, basándose exclusivamente en motivos de índole religiosa o moral, y debe garantizar al fiel el derecho a ser escuchado y la posibilidad de recurrirla en sede canónica. En segundo término, el control de adecuación de esta decisión episcopal al orden constitucional de los derechos y libertades fundamentales que deben llevar a cabo los órganos jurisdiccionales del Estado en caso de impugnación en el orden civil, unido a la incompetencia de éstos para sustituir el juicio de idoneidad que sólo a la autoridad religiosa compete, demanda que los criterios morales o religiosos en que se funda deban estar necesariamente explicitados o, en su defecto, que se requiera a la confesión para que los mani- 
fieste. Y, en tercer lugar, la normativa laboral a la que está sujeta la Administración -en cuanto empleadora- a la hora de hacer efectivo el cese le exige la comunicación escrita al trabajador expresando la causa (art. 53.1.a) Estatuto de los Trabajadores ${ }^{29}$. Tal como se ha adelantado, intuimos que esta omisión podría encontrar una posible explicación en que el Tribunal Constitucional niegue relevancia constitucional a la forma en que se ha llevado a cabo la revocación, por ser una cuestión que pertenece estrictamente a la esfera de la legalidad ordinaria, sin embargo, también a esto hemos objetado el innegable papel basilar que la motivación de la revocación ocupa a la hora de ejercer el profesor sus medios de defensa en juicio.

Para concluir este epígrafe, y sin perjuicio de lo anterior, resulta conveniente insistir de nuevo en que la razonable consistencia de los motivos alegados junto al valor indiciario del silencio del obispo deberían haber servido también para trasladar al ordinario la carga de probar que la falta de propuesta realmente no respondía a ningún propósito atentatorio de los derechos de la profesora de religión por estar basada en causas exclusivamente religiosas o morales. Sólo de este modo quedaría adecuadamente contrarrestada la enorme dificultad que la reserva en la esfera intraeclesial de las razones de la revocación entraña para las posibilidades del profesor de demostrar el eventual carácter lesivo de alguno de sus derechos de esta decisión-siempre que éste goce de cierta entidad, claro- así como para el cumplimiento de la obligación impuesta a los órganos judiciales competentes de examinar si otros motivos, que no sean los estrictamente religiosos, han intervenido en la decisión de no proponer al candidato, ya que solamente estos últimos están protegidos por el principio de libertad religiosa.

\subsection{La postura del Tribunal Supremo}

El planteamiento del Tribunal Constitucional descrito contrasta con el mantenido por el Tribunal Supremo en una sucesión de sentencias ${ }^{30}$, dictadas entre 2008 y 2009, que han de enmarcarse en el contexto de las numerosas de-

${ }^{29}$ Este artículo, recordemos, regula la forma y efectos del despido por causas objetivas, en este caso por ineptitud sobrevenida.

30 SSTS de 14 de enero de 2009 (STS 1464/2009), de 20 de enero de 2009 (STS 661/2009), de 28 de enero de 2009 (STS 1200/2009), de 28 de enero de 2009 (STS 674/2009), de 30 de enero de 2009 (STS 1682/2009), de 2 de febrero de 2009 (STS 1781/2009), de 6 de mayo de 2009 (STS $3340 / 2009)$. 
mandas por despido nulo interpuestas por profesores de religión de Canarias, a los que se les había retirado la venia docenti como represalia por su actividad sindical y su participación en huelgas y encierros en señal de protesta por sus condiciones laborales. En la totalidad de los casos resueltos, los profesores habían visto satisfechas sus pretensiones en primera instancia por los Juzgados de lo Social, e incluso dichos pronunciamientos favorables habían sido posteriormente confirmados por el Tribunal Superior de Justicia de Canarias ${ }^{31}$. El Tribunal Supremo se mantiene en la misma línea que ellos, de ahí que convenga especificar los puntos clave de la solución interpretativa y fundamentadora, que todos comparten en el sentido de sus fallos. En este orden de ideas, se abordarán, en lo que sigue, dos cuestiones básicas. En primer lugar, la apreciación de la suficiencia de acreditación del panorama lesivo -tal y como exigen las reglas de la prueba indiciaria- y, en segundo término, los efectos de la falta de motivación previa y posterior justificación por parte de la autoridad eclesiástica de que su decisión no obedece a motivos prohibidos por discriminatorios, en orden, de un lado, a la confirmación de la vulneración denunciada y, de otro, a la declaración de nulidad del despido.

Por lo que se refiere a la primera, ha de decirse que el juicio de razonabilidad de los indicios de discriminación aportados se resuelve en un sentido positivo en primera instancia y resulta indiscutido, salvo en una de las sentencias, en las siguientes instancias. En todos los casos los juzgados de lo social consideraron fundada la sospecha de lesión de sus derechos fundamentales a partir de la alegación y prueba fehaciente por los profesores de su participación en las huelgas y encierros, así como su condición de miembros de organizaciones sindicales y, en general, su activa colaboración en una larga serie de conflictos dirigidos a lograr su estabilidad en el empleo. Sobre este extremo, resulta conveniente, además, llamar la atención acerca de que los hechos aducidos se produjeron fundamentalmente entre finales de $1999 \mathrm{y}$ principios de 2000, lo que no fue óbice para que los profesores fueran propuestos para el curso 2000-2001, produciéndose su exclusión de la lista de habilitados al curso siguiente, lo que demuestra la limitada trascendencia de la proximidad en el tiempo entre las circunstancias alegadas y la decisión impugnada para apreciar la relación de causalidad entre ambas, en contra de lo que sostiene el Tribunal Constitucional en la sentencia analizada.

31 A excepción de la STSJ Canarias de 28 de marzo de 2007, que revocó la SJS no 4 de Santa Cruz de Tenerife de 10 de febrero de 2006. 
Paralelamente, consideramos procedente detenernos en la valoración de la existencia de indicios de discriminación que hace la sentencia del Tribunal Supremo de 20 de enero de 2009. Ésta resulta particularmente interesante porque es el único caso en que el Tribunal Supremo se pronuncia sobre este particular, ya en todas las demás sentencias, como se ha dicho, esta cuestión no había sido objeto de controversia. En este caso, el Tribunal Supremo concluye que en la sentencia recurrida el Tribunal Superior de Justicia de Canarias ha aplicado una doctrina restrictiva de las exigencias fácticas y jurídicas inherentes al juego de la carga probatoria en estos supuestos al no considerar suficientemente acreditado el escenario lesivo. En la fundamentación de su fallo hace un repaso de una larga serie de sentencias del Tribunal Constitucional, en las que este último asienta el criterio de que para desplazar al empresario el onus probandi «no basta simplemente con que el trabajador afirme su carácter discriminatorio [STC 266/1993, de 20 de septiembre, FJ 2], sino que ha de acreditar la existencia de indicio que "debe permitir deducir la posibilidad de que aquélla [la vulneración constitucional] se haya producido" [SSTC 114/1989, de 22 de junio, FJ 5; 85/1995, de 6 de junio, FJ 4] [SSTC 144/2005, de 6 de junio, FJ 3; 171/2005, de 20 de junio, FJ 3], que genere una razonable sospecha, apariencia o presunción en favor de semejante afirmación; es necesario que por parte del actor se aporte una "prueba verosímil" [STC 207/2001, de 22 de octubre, FJ 5] o "principio de prueba" revelador de la existencia de un panorama discriminatorio general o de hechos de los que surja la sospecha vehemente de una discriminación, sin que sea suficiente la mera afirmación de la discriminación [por todas, SSTC 308/2000, de 18 de diciembre, FJ 3; 41/2002, de 25 de febrero, FJ 3; 17/2003, de 30 de enero, FJ 3; 98/2003, de 2 de junio, FJ 2; 188/2004, de 2 de noviembre, FJ 4; 38/2005, de 28 de febrero, FJ 3; 175/2005, de 4 de julio, FJ 4; 326/2005, de 12 de diciembre, FJ 6; 138/2006, de 8 de mayo, FJ 5; 168/2006, de 5 de junio, FJ 4; 342/2006, de 11 de diciembre, FJ 4]». A la vista de lo anterior, pueden extraerse las siguientes conclusiones: en primer lugar, no basta con la mera afirmación de la existencia de un despido discriminatorio o lesivo de un derecho fundamental; en segundo lugar, tal afirmación ha de reflejarse en unos hechos de los que resulte una presunción o apariencia de que aquella discriminación o lesión se ha producido. En el caso planteado, el profesor de religión no se limita a afirmar que su despido es discriminatorio, sino que alega y prueba su actividad sindical, a la que tanto el Juzgado de lo Social como el Tribunal Supremo conceden entidad suficiente para sustentar una fundada sospecha de discriminación. Sin embargo, exigir al trabajador -en este 
caso, profesor de religión- que demuestre una conexión necesaria o relación de causalidad entre los hechos alegados y la decisión impugnada, como hace la sentencia del Tribunal Constitucional 140/2014 ${ }^{32}$-más arriba comentada-, constituye, a nuestro entender, una exigencia desproporcionada con respecto a su doctrina anterior, que de ningún modo puede interpretarse como una conexión directa y real, ya que ello convertiría en algo meramente anecdótico la inversión probatoria hacia el empresario. Por consiguiente, desde nuestro punto de vista, dicha conexión sólo resulta admisible si se interpreta en el sentido de aquella sospecha, presunción o apariencia.

Siguiendo con nuestro análisis, y de acuerdo con las reglas de la prueba indiciaria, ante la aportación de un panorama lesivo por parte del trabajador -en nuestro caso, por los profesores de religión-, corresponde al empresario la carga de probar que los hechos motivadores de su decisión han sido absolutamente ajenos a todo móvil atentatorio de los derechos fundamentales de aquél. Sin embargo, en los casos planteados en las sentencias analizadas el obispado omitió toda explicación justificativa de su conducta que permitiera excluir la presencia de motivos prohibidos por discriminatorios, a lo que habría de añadirse que esta consciente dejadez llevaría aparejada la importante consecuencia de la declaración de firmeza de la lesión denunciada, en línea -como recuerda la sentencia del Tribunal Supremo de 20 de enero de 2009con la doctrina del Tribunal Constitucional, según la cual «la ausencia de prueba trasciende de este modo el ámbito puramente procesal y determina, en último término, que los indicios aportados por el demandante desplieguen toda su operatividad para declarar la lesión del propio derecho fundamental [SSTC 197/1990, de 29 de noviembre, FJ 4; 136/1996, de 23 de julio, FJ 4] [SSTC 326/2005, de 12 de diciembre, FJ 6; 138/2006, de 8 de mayo, FJ 5; y 168/2006, de 5 de junio, FJ 4]. En consecuencia, entiende la Sala que la no renovación del contrato al actor atenta a los derechos fundamentales que consa-

32 En cuyo fundamento jurídico 7 literalmente dice «el indicio razonable de que se ha producido la lesión del derecho fundamental no consiste en la mera constatación de que en un momento precedente tuvo lugar el ejercicio del derecho -en este caso que se participó en una huelga o en que se formuló una reclamación judicial- sino que es preciso justificar-indiciariamente- la existencia de una relación de causalidad entre tal ejercicio y la decisión o acto calificado de lesivo del derecho. El que en un momento pasado se haya ejercitado un derecho fundamental constituye un presupuesto de la posibilidad misma de la violación denunciada, pero no un indicio de ésta que por sí solo desplace a la otra parte la obligación de probar la regularidad constitucional de su acto, pues la aportación de la prueba que concierne a la parte demandante deberá superar inexcusablemente el umbral mínimo de aquella conexión necesaria». 
gra nuestra Constitución, [...] y, además, que ha quedado acreditada la conducta vulneradora, puesto que las no renovaciones de los contratos se deben a la participación del actor en la actividad sindical y a las reclamaciones judiciales interpuestas ostentando la defensa de otros profesores de religión ${ }^{33}$.

De modo que, en las sentencias objeto de estudio, puede identificarse una secuencia que comienza con la acreditación de indicios de discriminación, continúa con la ausencia de prueba en contrario por la parte demandada, lo que conlleva el reconocimiento definitivo y en firme de la vulneración denunciada, por lo que nos restaría referirnos al corolario final de este silogismo, que vendría cifrado por la declaración de nulidad del despido o cese. Como muestra de este último extremo puede citarse por todas la sentencia del Tribunal Supremo de 28 de enero de 2009, en cuyo fundamento jurídico noveno declara que cuando «se tiene por acreditada la lesión de derechos fundamentales, como aquí ha ocurrido y no se discute en esta sede, cabe afirmar -en sintonía con la decisión adoptada por el Tribunal Constitucional en su sentencia 173/1994 de 7 de junio- que es obligado declarar la nulidad del acto lesivo y adoptar las medidas que en cada caso sean necesarias para restablecer la situación existente en el momento anterior a producirse la lesión. Por consiguiente, como quiera que en este caso la decisión que se ha considerado lesiva de los derechos fundamentales del trabajador ha constituido el único obstáculo para la renovación automática de su nombramiento, la forma de restablecer la normalidad jurídica debe ser aplicar los mismos efectos que el art. 55.5 ET prevé para las decisiones extintivas del empresario que impiden la continuidad del vínculo laboral -aquí la falta de renovación automática- y son calificadas de despido nulo por vulneración de un derecho fundamental».

A la vista de lo anterior, y retomando el objeto del presente apartado -la motivación tras la impugnación judicial de la decisión de revocación-, convie-

${ }^{33}$ FJ 6. Asimismo, resulta particularmente representativa a este respecto la sentencia del Tribunal Superior de Justicia de Canarias de 31 de enero de 2008 (STSJ ICAN 360/2008), dictada también en el marco de las reclamaciones judiciales por despido protagonizadas por los profesores de religión canarios, en la que la Sala concluye que «la no renovación obedeció a la participación de la trabajadora en la huelga y a su actitud conflictiva, participando, asimismo en los encierros que se produjeron; a lo que hay que añadir que no se ha alegado razón alguna para explicar por qué motivo después de años de idoneidad se la considera inidónea. No hay en autos explicación alguna y lo único que se hace es invocar la facultad libérrima del Obispado para proponer a los profesores de religión. Frente a tal falta de motivación se alza como indicio fundamental, razonable y suficiente el hecho de la participación de la actora en huelgas y encierros, que producen como resultado último la no renovación de la demandante y de otros compañeros que igualmente se significaron participando en aquéllos». 
ne aclarar que la aplicación de la doctrina del Tribunal Constitucional acerca de la tutela del trabajador frente a decisiones empresariales de no renovación del vínculo laboral enmarcadas en su libertad de contratación, que pudieran ser tachadas de discriminatorias, y las reglas de la prueba indiciaria, al control judicial de las revocaciones no justificadas de idoneidad, con la consiguiente no propuesta de los profesores de religión, puede plantear en cierto modo -además de las distorsiones apuntadas más atrás en el presente trabajo- un menoscabo de la exclusiva atribución de las confesiones para juzgar, atendiendo a criterios morales y religiosos, sobre la idoneidad del profesor de religión para impartir su respectivo credo. De manera que, como se ha visto, cuando la confesión tampoco justifica su decisión después de ser impugnada judicialmente -siempre que se haya acreditado previamente el panorama lesivo-, el órgano jurisdiccional acaba ocupando la insustituible posición de la confesión para decidir acerca de la condición de idóneo del profesor de religión y, por ende, su continuación prestando servicios como tal. Este mismo interrogante le surge a López-Sidro cuando expone que esta doctrina sentada por el Tribunal Supremo, en virtud de la cual «la falta de motivación formalizada en los juicios negativos de idoneidad que conducen a la autoridad eclesiástica a dejar de proponer a un profesor de Religión para su contratación como docente en el próximo curso, si concurre con un panorama lesivo de los derechos fundamentales, puede ser suficiente para considerar aquella decisión nula de pleno derecho abre el debate sobre si las decisiones judiciales, en caso de ausencia de motivación, pueden arrogarse el derecho a hacer ese juicio de idoneidad en lugar del Obispado, lo que no parece posible sin vulnerar la autonomía de las confesiones religiosas» ${ }^{34}$. En un sentido más categórico se manifiesta Cañamares cuando sostiene que, ante la falta de motivación, no cabe que «el Tribunal entre a explicitar la que, a su juicio, constituiría el fundamento de la falta de propuesta, pues ello supondría sustituir el juicio religioso que corresponde en exclusiva a la autoridad diocesana por la valoración del juzgador, determinando una intromisión en un ámbito exclusivo de la confesión religiosa que

\footnotetext{
34 A. LópeZ-Sidro, Virtualidad de la motivación religiosa en la pérdida de idoneidad del profesorado de religión católica, Ius Canonicum 51 (2011) 642. Ruano Espina también se refiere a esta sustitución del juicio de la autoridad eclesiástica por la decisión del órgano jurisdiccional «como una restricción injustificada de la autonomía de la Iglesia». L. RUANO EsPINA, El modelo español de enseñanza de la religión católica en la escuela pública, en I. CANO RUIZ (ed.), La enseñanza de la religión en la escuela pública. Actas del VI Simposio Internacional de Derecho Concordatario, Comares, Granada $2014,113-114$.
} 
determina la vulneración de su derecho de libertad religiosa y, además, la conculcación del principio de neutralidad religiosa del Estado ${ }^{35}$.

No obstante, frente a la opinión de estos autores, consideramos que puede objetarse que la exigencia a la confesión de que justifique que su decisión es ajena a cualquier propósito atentatorio de los derechos fundamentales del profesor no tiene que ir necesariamente en contra de su libertad para decidir acerca de la idoneidad -o la falta de ésta- de sus profesores, dado que el órgano jurisdiccional, antes de resolver en el sentido de dar la razón al profesor y declarar la nulidad del cese, ha concedido a la autoridad eclesiástica la posibilidad de demostrar que la revocación de la idoneidad respondía a una motivación puramente religiosa o moral. Por consiguiente, lo que realmente se exige a la confesión es que dé razones de los motivos de la revocación, algo a lo que, como se ha visto en el anterior apartado, está obligada incluso desde el momento en que adopta dicha resolución -tanto en el plano del Derecho Canónico como del Derecho estatal-, pero no se le priva en absoluto de su libérrima facultad para disponer sobre la aptitud moral y religiosa de los profesores que imparten su credo. Ahora bien, lo que de ningún modo resulta admisible es una utilización de esta facultad lesiva de los derechos fundamentales del profesor. Recuérdese, en este sentido, la sentencia del Tribunal Constitucional 38/2007 -referida al comienzo del presente trabajo-, en la que puntualiza que «por más que haya de respetarse la libertad de criterio de las confesiones a la hora de establecer los contenidos de las enseñanzas religiosas y los criterios con arreglo a los cuales determinen la concurrencia de la cualificación necesaria para la contratación de una persona como profesor de su doctrina, tal libertad no es en modo alguno absoluta, como tampoco lo son los derechos reconocidos en el art. 16 CE ni en ningún otro precepto de la Constitución, pues en todo caso han de operar las exigencias inexcusables de indemnidad del orden constitucional de valores y principios cifrado en la cláusula del orden público constitucional». Igualmente, compartimos el parecer del Tribunal Supremo mantenido en su sentencia de 28 de enero de 2009, en la que, apoyándose en la doctrina del Tribunal Constitucional, expresa:

«especial interés tienen las sentencias del Tribunal Constitucional sobre la extinción del contrato de trabajo en el periodo de prueba, pues la le-

35 S. CAÑAmARES, El control jurisdiccional de la autonomía de la Iglesia Católica en la designación de los profesores de religión, Revista Española de Derecho Canónico 66 (2009) 288-289. 
gislación laboral establece en este caso la posibilidad de un desistimiento, liberando a las partes de motivar la decisión extintiva (artículo 14.2 del Estatuto de los Trabajadores). Sin embargo, la doctrina constitucional ha entendido que, aunque esto es así en el marco de la legalidad ordinaria, la situación cambia cuando el problema no se plantea como una cuestión de legalidad, sino en confrontación con un precepto constitucional que prohíbe toda discriminación o que garantiza un derecho fundamental y así se dice que "la motivación de la resolución del contrato de trabajo durante el periodo de prueba carecerá de trascendencia siempre que tenga cabida dentro del ámbito de libertad reconocido por el precepto legal, que evidentemente no alcanza a la producción de resultados inconstitucionales", pero esa motivación será necesaria cuando se trate de acreditar que tal facultad no se ha hecho "valer, por causas ajenas al propio trabajo, en contra de un derecho fundamental” (SSTC 94/1984 y 166/1988). También hay que mencionar la STC 173/1994 que resuelve sobre un supuesto en que la lesión del derecho fundamental se imputa a la no renovación de un contrato temporal. Pues bien, esta sentencia señala que "no puede mantenerse que no se ha producido una discriminación por el solo dato de que el empresario se ha limitado a ejercitar un acto de libertad al margen del contrato de trabajo", pues "la conducta empresarial, fundada en motivos expresamente prohibidos... no puede ser valorada como un mero acto de libertad indiferente para el Derecho" y, por ello, "la mera negativa a renovar un contrato o a contratar por parte del empresario, es jurídicamente relevante desde el momento en que a la luz de los hechos declarados probados, ha sido un motivo prohibido por discriminatorio el que ha obstado a la reanudación de la relación laboral, porque entra de lleno en el ámbito de aplicación del artículo 14 de la Constitución Española, y deben serle aparejadas las consecuencias lógicas que derivan de esta calificación" ${ }^{36}$.

La única matización que, desde nuestro punto de vista, debe hacerse es que en las sentencias aludidas por el Tribunal Supremo se hace referencia a un poder empresarial, inherente a la libertad de contratación, que permite al empresario resolver un contrato de trabajo -como ocurre en el periodo de prueba- o bien no renovarlo, sin necesidad de invocar causa alguna, aunque, como

36 FJ 3. 
se desprende de esta doctrina, la irrelevancia de la motivación desaparece cuando existen indicios de discriminación suficientes. Pero en el caso de las revocaciones de idoneidad, insistimos, no estamos ante decisiones no causales, sino que la autoridad eclesiástica se encuentra sujeta a condicionantes de orden moral o religioso, por lo que su margen de decisión es bastante más restringido que el de cualquier empresario. Además, como se ha visto, el Derecho canónico le obliga a motivar la revocación y dar audiencia al interesado; también le obliga el Derecho estatal, cuando regula la forma en que la Administración debe hacer efectivo el despido y, por supuesto, le obliga el orden constitucional, que se alza -como no podría ser de otro modo- como límite infranqueable para esta libertad. Por tanto, si no justifica su juicio negativo de idoneidad, ni antes ni después de ser impugnado el despido, correrá el riesgo de que éste sea anulado, pero su libertad para velar por la identidad católica y la recta doctrina de sus profesores de religión no habrá resultado menoscabada, ya que, como manifiesta el Tribunal Constitucional en su trascendental sentencia 38/2007, «son únicamente las Iglesias, y no el Estado, las que pueden determinar el contenido de la enseñanza religiosa a impartir y los requisitos de las personas capacitadas para impartirla dentro de la observancia, [...], de los derechos fundamentales y libertades públicas y del sistema de valores y principios constitucionales» ${ }^{37}$.

37 FJ 9. 


\section{Bibliografía}

BRAGE, J., La no renovación de contrato a los profesores de religión en las escuelas públicas por falta de idoneidad canónica (autonomias de las iglesias y aconfesionalidad del Estado VS. derechos fundamentales del trabajador). Comentario a las SSTC 38/2007 y 128/2007, UNED. Teoría y Realidad Constitucional 20 (2007) 633-655.

CABEZA, J., El control judicial sobre las decisiones episcopales relativas al profesorado de religión en centros públicos: comentario a una sentencia desafortunada con exabrupto en uno de los votos particulares. Sobre la STC 140/2014, de 11 de septiembre, Revista de Derecho Social 67 (2014) 145-168.

CAÑAmares, S., El control jurisdiccional de la autonomía de la Iglesia Católica en la designación de los profesores de religión, Revista Española de Derecho Canónico 66 (2009) 275-292.

Cardenal Carro, M. - Hierro Hierro, F. J., La evolución histórica de la regulación de los profesores de religión y moral católica como recurso para el juicio sobre la constitucionalidad de la vigente (A propósito de la STC 38/2007, de 15 de febrero), Revista del Ministerio de Trabajo e Inmigración 73 (2008) 205246.

CuBILlas, L. M., Confesionalidad y relación del profesor de religión católica en los centros públicos -Derecho español-, en M. Blanco - B. CAstillo - J. A. FuENTES - M. SÁNCHEZ LASHERAS (coords.), Ius et iura. Escritos de derecho eclesiástico y de derecho canónico en honor del profesor Juan Fornés, Comares, Granada 2010, 285-315.

FernáNDEZ MÁrquez, O., La designación del profesorado de religión y moral católica en centros públicos de enseñanza. Estado de la cuestión tras la STC 38/2007, de 15 de febrero, Revista Española de Derecho Constitucional 84 (2008) 285-335.

Ferreiro Galguera, J., Sistema de elección del profesorado de religión católica en la escuela pública: dudas de constitucionalidad sobre sus cimientos normativos (STC 38/2007), Revista General de Derecho Canónico y de Derecho Eclesiástico del Estado 14 (2007) en http://www.iustel.com.

Gómez-Millán Herencia, M. J., Incidencia del Real Decreto 696/2007 en la contratación laboral de los profesores de religión católica, Relaciones laborales: Revista crítica de teoría y práctica 2 (2007) 1047-1075.

GonZÁLEZ, A., Dos oportunidades perdidas. A propósito del control de la constitucionalidad de la designación por parte de la Iglesia de los profesores de religión en la escuela pública, Revista General de Derecho Constitucional 6 (2008) 1-27. 
Llamazares, D., Contratación laboral de los profesores de religión católica por la Administración Pública (Comentario a la STC 38/2007, de 15 de febrero), Revista Española de Derecho Constitucional 80 (2007) 267-315.

LÓPEZ-SIDRO, A., Virtualidad de la motivación religiosa en la pérdida de idoneidad del profesorado de religión católica, Ius Canonicum 51 (2011) 627-652.

Moreneo AtienZA, C., La contratación de profesores de religión: control jurisdiccional de la declaración de idoneidad eclesiástica a raíz de la violación de los derechos fundamentales del trabajador (Comentario a la STC 38/2007, de 15 de febrero de 2007), Tribuna social: Revista de seguridad social y laboral 202 (2007) 47-51.

Moreno Botella, G., Autonomía de la Iglesia, profesorado de religión y constitucionalidad del Acuerdo sobre enseñanza de 3 de enero de 1979. A propósito de la STC 38/2007 de 15 de febrero, Revista General de Derecho Canónico y de Derecho Eclesiástico del Estado 14 (2007) en http://www.iustel.com.

Motilla de la Calle, A., Consideraciones en torno al status jurídico de los profesores de religión católica (comentario de la STC 38/2007), Revista de la Facultad de Derecho de la Universidad de Granada 11 (2008) 257-267.

OtADUy GuERÍN, J., Idoneidad de los profesores de religión. Una revisión necesaria y urgente. A propósito de la sentencia 38/2007, de 15 de febrero, del Tribunal Constitucional, Revista General de Derecho Canónico y de Derecho Eclesiástico del Estado 14 (2007) en http://www.iustel.com.

—, La idoneidad de los profesores de religión católica y su desarrollo jurisprudencial en España, Estudios Eclesiásticos 88 (2013) 849-871.

-, Relación jurídica de los profesores de religión en España. La dimensión canónica, Ius Canonicum 92 (2006) 445-484.

Rodríguez Blanco, M., El régimen jurídico de los profesores de religión en centros docentes públicos, Il diritto ecclesiastico 112/2 (2001) 482-573.

—, El régimen jurídico de los profesores de religión y moral católicas, en M. CAMPO IBáÑ̃z (ed.), Problemáticas y respuestas. Realidad actual y Derecho canónico. Actas de las XXXIII Fornadas de Actualidad Canónica, Dykinson, Madrid 2014, 109-138.

RuANO EsPINA, L., El modelo español de enseñanza de la religión católica en la escuela pública, en I. CANO RUIZ (ed.), La enseñanza de la religión en la escuela pública. Actas del VI Simposio Internacional de Derecho Concordatario, Comares, Granada 2014, 81-120. 